River' slates in Orange county, N.Y., and $\epsilon$ lsewhere." 1

In this paper I described the finding of Trenton fossils in slates that Emmons had always considered to be of Taconic age ; and Professor Mather's ${ }^{2}$ statement that the remains of 'Testacea' were found at certain localities in these states appears to have been overlooked in Emmons's latest discussion of the sub. ject (likewise in that of Dr. Hunt ${ }^{3}$ ). In calling attention to the nature of these remains, and adding a new locality, with descriptions of the structure of the beds, I was only presenting bare statements of facts; but, in consideration of the Taconic theory, I employed the words Fossils in the Hudson River slates,' etc., rather than 'Trenton fossils in the Taconian argillite.' in my title.

It can be readily understood how isolated patches of Utica slates could extend along the Hudson valley as far south as noted by Booth ; ${ }^{4}$ but my observations, together with those of Dale, ${ }^{5}$ show the occurrence of Trenton fossils in beds at several widely separated points in the slate belt (I have discovered other localities since $\mathrm{my}$ paper), and point to the age of the great mass of these slates as post-Potsdam. An examination of the relations at Rock Tavern and at Sugar Loaf plainly proves that the fossiliferous beds are not isolated patches, and that neither are they superficial layers enclosed in synclinal folds, nor brought to their present positions by faulting.

In this connection it may be well to state that for some time the writer has been engaged upon a very detailed study of the structure of these slates, and the associated limestones and other formations. Many paleontological and stratigraphical discoveries have been made which will solve some of the problems of their ages and relations. A portion of the results of this work will be ready for publication early in the next summer.

Brooklyn, N.Y.

Nelson H. Darton.

\section{The temperature of the moon.}

I hope that Professor Ferrel and I have no real ground of dispute : I may at least think so, since he does not deny that he begins by speaking of a certain body endowed by hypothesis with peculiar properties ; such. for instance, as imply invisibility. Professor Ferrel, as I now understand him, explains that this implication is non-essential, and merely an analytical device to explain what would take place on a certain sphere, on which (by hypothesis still) the relative radiating and absorbing powers of every part are not merely proportional for any given ray, but to be safely treated as absolutely and without restriction equal, - a sphere on which, instead of physical approximations, we have absolute truths, which, like the axioms of Euclid, can be safely pushed to their extremest consequences.

This sphere it is my complaint that Professor Ferrel identifies with the moon, though it also seems to be a homogeneous body, not a world of irregular surface and structure; a body freed from changes of temperature, and which (unless infinitely conductible) would appear to need, not to alter its distance from the sun or rotate on its axis, - an absolutely

1 Amer. journ. sc. (3d ser.), xxx. p. 452, 1885.

2 Final report, 1843 , p. 369.

3 The Taconic question, Trans, Roy. soc. Canada, vol. i.

${ }^{4}$ Amer. journ. sc. (3d ser.), xxvi. p. 380, 1883.

5 Ibid., xvii. p. 57, 1879. airless body; and sn on, through a really endless list of limitations, which we should find, on scrutiny, latent in his premises. Under these limitations, I do not dispute any of his conclusions; nor, when I say that no actual body in nature does exist under them, do $I$ at all deny his right to consider one which by hypothesis shall do so, nor the interest of such an inquiry. I only call the reader's attention to the undoubted fact that the real moon exists under quite other ones. While I do not for a moment admit that the temperature of the real moon is independent of the amount of heat which it rejects by reflection, I can readily agree that it might be quite immaterial to the temperature of this hypothetical moon. I have no disposition to treat such an hypothesis as idle: I acknowledge its interest, and, I may add, its utility, if employed under clearly recognized limitations.

I recognize with respect the accuracy of the logical process always at Professor Ferrel's command; but, I repeat, the more accurate it is, the more certain it is to deduce only such conclusions as are implicitly contained in its premises.

Though he himself refers in part to these limitations at the outset. the general reader may certainly require to be reminded that they are not embraced in Professor Ferrel's conclusions, which may well be deduced from commenly made assumptions, by correct reasoning, as to a hypothetical moon, and yet not apply without limitation to the real one which we see waxing and waning in the sky. This is all I have to say, and I leare to Professor Ferrel the last word in this friendly controversy if he chooses to add it.

S. P. LANGLEY.

Allegheny observatory, Jan. 12.

\section{Demand for good maps.}

I am very glad that you have taken upon yourself to criticise our maps and the map-makers' methods, and sincerely hope that you may succeed in so stirring up the publishers that they will feel compelled to abandon the habit of servilely copying ancient, and ofttimes obsolete examples. I have been seriously inconvenienced at times, particularly when giving instruction in geography, by the outrageous carelessness, not to say gross ignorance, displayed by our leading cartographical institutions.

I heartily concur in what Mr. C. H. Leete says concerning the German maps. We are far indeed from their standard. Why is it? It is no exaggeration to say that the cheap German school-atias, to which Mr. Leete refers, is much more reliable, and more nearly up to date, even in the geography of the United States of America, than the most expensive of our home productions.

Some years ago the travelling agent of one of our leading map-publishing houses called upon me, and insisted upon showing me their latest atlas, revised and corrected to date. I gave him every opportunity to explain the superior excellence of his wares, and, after he had had his say for over half an hour, I showed him that most of his maps were exact copies of those published from five to twenty-five years previously, the only apparent change being in the shades and elaboration of colors. Why, actually, though this was scarcely five years ago, the map of New York city showed the 'Crystal Palace'! Even where details appeared to fill in former blanks, more than one-third were mere guesses, and about as good 
guesses as the 'Golden City,' Colorado, to which you called attention some time ago.

Smithson. inst., Washington, Jan. 13.

J. KING GOODRICH.

\section{Cliff-picture in Colorado.}

The accompanying print is from a photograph of a remarkable formation which may be deemed worthy of mention. The original photographic print was sent to the military academy, about twelve years ago, by Capt. (then Lieut.) George S. Anderson, sixth U. S. cavalry. I have lately obtained from Captain Anderson the following statement in regard to the object. His statement is from memory, after the lapse of a dozen years; but it is not probable that there is any material error in it, as he went to considerable trouble to secure the photograph. The natural picture is on the face of the sandstone cliff forming the west bluff of the Purgatoire River, Colorado, twenty miles from its mouth, and twentyfive miles from Fort Lyons. The total height of the cliff at the point is about seventy feet above the bed of the river. The picture is about thirty-five feet above the stream, with twenty-five feet of vertical cliff above it. The talus of the cliff extends up about thirty feet, so that there are about five feet of vertical wall between the picture and the loose rock below.

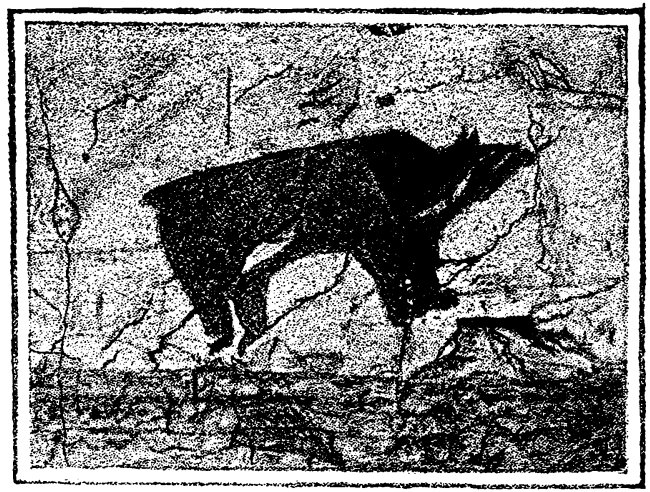

The extreme length of the picture is at least seven feet. The cliff is composed of brownish-red sandstone : the picture at the surface is of a much darker color, which color gradually passes into the uniform color of the rock, at a distance of $2 \frac{1}{2}$ " or 3 " from surface, as shown by detachable fragments. Copies of the photograph were sent, at the time it was taken, to Prof. Joseph Henry, Professor Dana. and to Darwin. Professor Henry asked, "Can it be any thing else than a work of Indian art?" Professor Dana thought the color due to iron stains, and the outline accidental. Darwin hesitated to express an opinion, but dissented from Professor Dana. Colonel Kendrick, formerly professor at the military academy, expressed the same opinion as did Professor Dana.

The figure is remarkably distinct and well defined for the result of accident: but, if Professor Henry's idea be rejected, there seems no other explanation.

West Point, N.Y.

\section{The English sparrow.}

A European ornithological journal recently contained the following testimony in regard to the sparrow (Pyrgita domestica), from the pen of Dr. Schleh, professor of agriculture at the College of agriculture, Herford, Germany. Dr. Schleh has paid a great deal of attention to this matter, and believes the sparrow a pest on the continent, voluminous evidence of which he is suid to have brought forward in his small treatise entitled 'Der nutze und schaden des sperlings ( $P$. domesticus) im haushalte der natur.'

By examining the crops of a great number of nestling sparrows sent to him from different parts of the country, he found that young sparrows, while in the nest and for a week after having left it, subsist entirely on insects, grubs, etc. Two weeks after leaving the nest, their food still consists of 43 per cent of animal food; a week later of 31 per cent, and after that age of only 19 per cent, of animal ingredients. But as soon as they become independent of their parents, they prefer seeds, and subsist almost entirely on grain, fruit, and the buds of trees. Dr. Schleh, however, mentions some interesting instances regarding some specimens which seemed to have a peculiar taste for the seeds of weeds which often become a great plague to the agriculturist. In one crop he found the considerable number of 321 whole seeds of Stellaria media (Vill.), in another 43 seeds of Atriplex patulum (L.), in a third 66 seeds of Setaria verticillata. Some individuals also have a special liking for certain insects. Thus he found in one crop 90 specimens of Haltica affinis (Gyll.): four other sparrows had eaten almost nothing else but a certain kind of beetle, Anisoplia fructicola (F.).

ERNEST INGERSOLL.

\section{Equality in ability of the young of the human species.}

The review of a rccent work on geometry, in Science, Jan. 1, is very justly criticised by W. R. in the number for Jan. 8.

Nothing is more fallacious than that ancestors have much to do with natural endowments : environment has much, and pre-natal influences probably most of all, in determining mental qualities. Physical traits are to some extent traceable to ancestry ; but the whole history of the race, and of our country in particular, is a refutation of the much studied hereditary genius, or transmitted mental quality.

Even the writer's comparison is unfortunate. Nothing seems more like chance than the development of a race-horse. When the truth is known of our most celebrated mile-in-two-fourteen trotters, they will be found to have been picked up here and there from the peddler's cart or from the farm. Their qualities accidentally discovered, and fictitious pedigrees made up for them, they have never left a racing progeny behind them.

I fully agree with N. E. in saying, " Better assume that the young are born equal in ability, and in their early training... give them an equal chance to develop into mechanics, store-keepers, artists, farmers, or lawsers ;" but by all means give them a chance to follow the bent of their intellect as soon as they are old enough to differentiate it, as, for instance, in their college courses.

P. J. FaRnswORTH.

Clinton, Io., Jan. 12. 